\title{
Breaking the myth of neutrality: Technology Assessment has politics, Technology Assessment as politics
}

\author{
Pierre Delvenne and Céline Parotte \\ SPIRAL Research Centre, University of Liège \\ Accepted manuscript (June 2018) to Technological Forecasting and Social Change
}

\begin{abstract}
:
This article aims at theoretically and pragmatically addressing the future roles of Technology Assessment (TA) communities in the challenging context of contemporary politics. Mobilizing Chantal Mouffe's theory of pluralistic agonism, we argue that TA communities should break with the myth of neutrality to render their political identities explicit and to recognize that TA does not only have politics, it also is politics. To do so, the notion of 'constitutive outside' is mobilized as a guiding methodological principle to invent a politics of TA. Three sites of politics where to define such a 'constitutive outside' are suggested: the values, the visions of the future, and the hegemonic and counter-hegemonic practices. We conclude that with a full awareness of its politics, TA communities should be able, on the one hand, to gain the trust and active support of political actors committed to the same ideals of democracy and knowledge-based policy-making. On the other hand, TA communities will also be able to distinguish TA supporters and adversaries and, consequently, reinforce their power of influence on policy-making. In a time of political uncertainty and epistemic ambiguity, TA communities may become a bastion of democratic politics.
\end{abstract}

Keywords: Myth of neutrality; politics of TA; constitutive outside; political identities; pluralistic agonism; TA futures.

\section{Introduction}

Technology Assessment (TA) communities ${ }^{1}$ should worry about contemporary politics. They should do so, because of their commitment to analytic and democratic practices (Van

\footnotetext{
${ }^{1}$ At the regional, national or international levels, the practice of Technology Assessment is structured by different, sometimes overlapping, communities. "Communities of practices are groups of people who share a concern or a passion for something they do and learn how to do it better as they interact regularly" (Wenger \& Trayner 2015: 1). In the current TA landscape, a concrete and structuring instance of TA community building at the international level is the European Parliamentary Technology Assessment (EPTA) network. Another example is the German-speaking TA community, which is also structured on a cross-national basis with organizational members from Germany, Austria and Switzerland as well as individual participants from other European countries. Lastly, around the label "TA-like activities", a number of actors collaborate, in European
} 
Est and Brom 2010), and especially because of the recent turnovers among their main addressees, parliamentarians and policy-makers. At first glance, this could be considered business as usual: shifts in political majorities and the renewal of political elites have become part of established routines despite being an enduring challenge for TA institutions. But with a closer look at the kind of turnover that occurs within most polities in the heartland of TA, the Western world, there are reasons to fear a shift in the normative assumptions underpinning many visions of knowledge and expertise for policy-making.

In an ever-increasing list of countries, populist or extremist leaders have achieved unprecedented electoral successes by appealing to people's fears and anger. When only looking at the last couple of years' political events, one may be easily overcome by dizziness: a UK referendum led to Brexit in June 2016 after the "Leave" partisans led by extreme-right leader Nigel Farage (UKIP) uttered infamous falsehoods, for instance that the UK was spending $£ 350 \mathrm{~m}$ a week in the European Union and that this amount could be used for the National Health System in the event of Brexit. In November of the same year, after a political campaign marked by disrespectful statements and countless lies, billionaire Donald Trump became the $45^{\text {th }}$ President of the United States and appointed white supremacists in the White House. His possible alter ego, Andrej Babis, qualified by the press as the "Czech Trump" due to his sharing of many traits with the "real Donald Trump" (the US President's name on Twitter), has just won the last legislative elections in Czech Republic. In September 2017 in Germany, an extreme right-wing and Europhobic political party, Alternative für Deutschland (AfD), gained almost 100 seats $(12,6 \%$ of the votes) and made a noticeable entry to the Bundestag, unprecedented since the end of Second World War. Less than a month later, in October 2017, Freiheitliche Partei Österreichs (FPÖ), an Extreme-right and anti-Semite party obtained more than $26 \%$ of the votes, turning the party's leader into the Austria's new ViceChancellor; the list may go on and on.

It is now a well-established reality: extreme-right, authoritarian and populist leaders in most countries across Europe - from the Netherlands to France, to Germany, Austria, Czech Republic, Belgium, Hungary or Poland-have taken their political parties on the road to solid progression and electoral success. Given these leaders' constant denigration of traditional expertise, one can cast some legitimate doubts on whether these newcomers care about TA,

projects or otherwise, in an active effort of naming and defining the practice of TA with regard to elements such as its scope, its disciplinary boundaries, its theoretical and epistemological foundations, the nature and content of the practice, its addressees or its working procedures (see Rosskamp 2017: 31-32). 
but Parliamentary TA (PTA) institutions need to get ready to be of service to their policy purposes.

This overwhelming flow of contemporary politics is powered by vociferous demands for a "radical change" to resorb a so-called "democratic deficit". Nevertheless, there should be no misunderstanding: in spite of seemingly congruent goals with "the history of TA's various attempts to address the democratic deficits of the modern practice of managing technology" (van Est and Brom 2010), the deficit many political leaders talk about these days is both likely to conclusively affect and substantially different to the context in which TA plays out. Anti-establishment proponents employ their rhetoric to target political and scientific elites and contest their ability to "tell the truth" about the "real world" or to "represent the real people". Scapegoating (for instance by vilifying the stranger, the migrant, the European Union), lying and bullshitting (Frankfurt 2009) have proved exceptionally efficient as engines of post-truth politics (Sismondo 2017, Lynch 2017, Jasanoff and Simmet 2017).

Contemporary politics, be it named "post-truth", "populist", "extremist" or "antiestablishment", is a game changer for Technology Assessment institutions. The situation is as much characterised by deep political cleavages as with epistemic ambiguity (Jasanoff and Simmet 2017). In other words, the shifting political power game is equally a shifting epistemic power game, in which TA has to compete with knowledge claims alien to its epistemologies. In an article for the Guardian, Steve Fuller (2016) presents a narrative of scientific lions and foxes to elaborate on the epistemic power game of science. Lions are described as traditionalist, operating in Kuhnian paradigms, legitimised by cumulative expertise. Foxes, however, are breakers of these traditions, they signify the revolutions that upset traditional paradigms. They lie in wait until the lion's narrative reveals imperfections and then use this opportunity to point out that the traditional way of looking at things might be wrong altogether. With this anthropomorphic story Fuller explains the outcome of the US election, as foxy Trump mercilessly pointed out the cracks in the traditional story of leonine Clinton. He successfully appealed to many Americans' emotions, resulting in breaking down the dominant political paradigm.

Wherever the cracks of the political paradigm as-we-know-it appear, the added value of TA as a source of expertise for policy-making may risk being questioned in new ways too. The recent de-institutionalization processes in Flanders and Denmark have been understood mostly in terms of unintended consequences of power politics which had little to do with criticisms of the very practice of TA or the quality of the knowledge produced (Delvenne et al. 2012, van Oudheusden et al. 2015, Delvenne et al. 2015, Hennen and Nierling 2015, 
Bütschi and Almeida 2016, Rosskamp 2017). But this new wave of "foxy" politicians may additionally consider that institutionalized TA embodies the establishment one needs to get rid of, as it misrepresents the concerned stakeholders, and is structurally unable to provide the knowledge that help decisions to be made. Whereas TA institutions have often been facing "hostile environment suspicious of a hidden anti-technocratic agenda held by TA" (Hennen and Nierling 2015: 5), what we see emerging is a new and equally threatening hostile environment to TA institutions. In the name of 'technological progress', the practice of TA has sometimes been criticized as 'technology arrestment'. Today's criticism may take another guise: TA's embodiment of, and proximity with the establishment may also lead to accusations of TA hampering 'truly' democratic policy-making.

As this special issue exhibits, TA communities themselves are beginning to wonder if it is still bearable and productive for TA to "restrict itself to the role of a 'knowledge broker' and refraining from taking a strong political stance in terms of recommending specific political action" (Hennen and Nierling 2017). This article's ambitions are animated by a willingness to address these issues in order to constructively contribute to shaping the future of TA. We suggest that it is possible for TA communities to disentangle from moral issues stemming from contemporary politics (i.e. should we help any politician? Can or should we be serviceable to any political project?) and (re)position themselves in the political terrain. To do so, as we show in section one, a necessary task as well as a tough challenge ahead for TA institutions is to decisively break with the myth of neutrality and fully acknowledge that TA has politics. Since the politics of TA is often about democratization of, or broader participation in, scientific and technological options for policy-making, TA communities need new conceptual resources to address their own 'democratic politics' and to confront this politics with others in the political terrain. In section two, we suggest that Chantal Mouffe's pluralistic agonism $(2000,2005,2013,2016)$ is a useful political theory for TA communities to face the aftershocks of current political earthquakes. Equipped with Mouffe's conceptual framework, we argue that TA institutions will be better able to render their political identities explicit, so to recognize that Technology Assessment does not only have politics, it also is politics. In section three, we recommend using the notion of 'constitutive outside' as a guiding methodological principle to invent a politics of TA. With no claim to exhaustivity, we point at three sites of politics where such a 'constitutive outside' may be defined: the values, the visions of the future, and the hegemonic and counter-hegemonic practices. We conclude that with a full awareness of its democratic politics, TA communities should be able to gain the trust and active support of political actors committed to their ideals of democracy and 
knowledge-based policy-making. Furthermore, wherever these actors are endangered, TA communities may play a role of a bastion of democratic politics, actively working at empowering allies and equally disempowering adversaries.

\section{Debunking the myth of neutrality: TA has politics}

To paraphrase Langdon Winner (1980), TA has politics, and that this is a potentially good thing not to be ashamed or afraid of.

Indeed, TA's practices and its scientific standards are typically associated with a political preference for more participatory or deliberative modes of decision-making (Delvenne et al. 2015, van Oudheusden et al. 2015, Delvenne 2017, Rosskamp 2017). As Rosskamp explains (2017: 77), "the plea to overcome merely science-based policy-advice is often reiterated on a normative basis in TA projects". In an interview subtitled "It's not just the science", the Director of the Danish Board of Technology, who at that time was also the coordinator of the European PACITA project ${ }^{2}$, stressed: "with knowledge-based policy you take into account the knowledge, experience and values of other stakeholders. If you take that out of policy, you're doing the wrong thing" (Van Kasteren, 2015: 16, emphasis added).

By implementing methods such as consensus conferences, citizen summits, future panels, scenario workshops, etc., TA generally sustains a broader inclusion of publics (previously excluded from decision-making processes) and contributes to bringing fresh ideas to support the representative democracy. Doing so, TA raises new questions, highlights alternative pathways, reduces the gap between parliamentarians and their constituencies, and reinforces the legitimacy of decisions. In other words, it is intended to make a difference in terms of the quality of decision-making by bringing additional and comprehensive knowledge in those policy processes (Decker and Ladikas 2004: 4). TA's rationales and normativities are thus committed to general ideals of "empowering" publics or "enlightening” policy.

The practice of TA supports particular visions of the world, about how it is and ought to be, and frames certain topics in line with these preexisting visions and ideas of where and how TA can make a meaningful contribution. To name but a few examples, striving for "healthier aging" or "sustainable consumption" (European PACITA Project), studying "mass surveillance and citizens' rights", or exploring ways of developing "collaborative economy" (STOA projects) indeed reveal and sustain particular preferences and visions of the world. In

\footnotetext{
${ }^{2}$ See the website of the PACITA (Parliaments and Civil Society in Technology Assessment) project (20112015): www.pacitaproject.eu.
} 
a policy report on the future of ageing (Barland and Lovett 2015), one finds explicit calls for action, for instance by urging European policy-makers to "develop long-term strategies that responsibly introduce technology and ensure basic care for everyone" (Barland and Lovett 2015: 17) or to "establish a mentality and culture for volunteering" (Barland and Lovett 2015: 20).

In other words, those preferences and commitments are not neutral because they sustain a particular vision of the world. Nevertheless, TA's political affiliations are often denied or downplayed across TA communities (van Oudheusden 2014, Hennen and Nierling 2015). TA is typically framed and presented as a neutral analytic activity aimed at providing decision makers with an objective analysis of a technology (van Eijndhoven 1997) and/or as a scientific, interactive and communicative tool that aims to enrich the basis for public debate and science and technology decision-making (Decker and Ladikas 2004, also see the EPTA website $\left.^{3}\right)$.

The claim of neutrality as a 'legitimating myth' for TA has undoubtedly been helpful to anchor the approach in evidence-based modes of policy-making and to position it as equidistant from all political parties. Nevertheless, we consider that its past usefulness and relevance should today be seriously reassessed. Looking at the past performance of neutrality in selected cases will allow to address that question: when TA was endangered or questioned, has the claim of 'being neutral' really been sufficiently protective to weather the storm? ${ }^{4}$

The demise of the American Office of Technology Assessment (OTA) is a welldocumented emblematic case (Kunkle 1995, Whiteman 1997, Wood 1997, Bereano 1997, LaPorte 1997, Blair 2013). In its early days, a crucial challenge for the OTA had consisted of taming the Republicans' suspicions that the office was a tool secretly in the hands of the Democratic party (Delvenne 2011, Hennen and Nierling 2015). This was notably due to its first Director, Emilio Daddario, who was overtly Democrat and also because many Democrats, such as senator Ted Kennedy, had shown a sustained interest in establishing a TA function in the Congress. Even while the OTA ultimately managed to successfully appear as equally serving both the Democratic and Republican parties, when the Republicans obtained the majority in both chambers in 1995 (what had not happened since the early 1950s), they decided to shut down the TA institution. Among many justifications for that closure, some

\footnotetext{
${ }^{3}$ http://www.eptanetwork.org/, accessed on November 14, 2017.

${ }^{4}$ The mirror question may also be asked: Where a TA institution successfully went through turbulences and questioning, was it thanks to the myth of neutrality? Even when a concrete causal link would be established, wouldn't it equally be possible to point at the acclaimed quality and robustness of the knowledge produced, or to claim that it was because powerful actors managed to defend the TA institution?
} 
Republican parliamentarians returned to claiming a lack of neutrality on the part of the OTA (LaPorte 2013). Thus, even when the neutrality myth is enforced (precariously, for the reasons just highlighted), it does not matter whether the TA board is governed through a series of checks and balances among political parties: the "lack of neutrality" argument comes back in the political debate anyway.

In the American de-institutionalization example, it should also be underlined the resistance of a part of the parliamentary administration, which considered that the work of the OTA was more like that of a think tank than a service for members of the Congress (Blair 2013), particularly when the OTA spoke on sensitive issues of defense or industrial policy (Mironesco 1997, Delvenne 2011). The point here is that whatever a TA may produce as an outcome of a study, even when the results would be presented in the most objective manner, there will always and immediately be criticisms pointing out so-called biases, as well as attempts at positioning the work being done in terms of politics. Members of Parliament or parliamentary administrations cannot be blamed for that: politics is the lens through which they look at the world.

Thomas Mann's famous quote (1924) should be remembered here: "everything is politics". Or at least, the boundary between science and politics is sometimes slimmer than it looks like. The golden age of the OTA was under the directorship of John Gibbons, a trained physicist who had no prior political belonging. Gibbons headed the OTA for 14 years and left in 1993, to become Bill Clinton's science and technology advisor. In an interview for an oral history of Bill Clinton's presidency (Gibbons and Johns 2006), Gibbons summarizes his career's evolution as follows:

I got dragged back into Washington from university life to be the director of the relatively new Office of Technology Assessment, which I had come to know a little bit and I saw as an important element of helping Congress and the American people have better access to highly technical information as it relates to policy issues. That work continued far longer-fourteen years-than I expected. When Clinton and [Albert] Gore were elected, they invited me to come down to the White House to be science advisor. In summary, I simply got on a slippery slope from basic science into I guess you would call it politics; I would just call it applied science (Gibbons and Johns 2006).

Either "politics" or "applied science", Gibbons chose to leave the legislative for the executive branch, to place his advisory skills at the service of a Democrat administration. By this, we also want to stress that his expertise accumulated as a successful TA director was perceived as valuable by and supportive of the Democratic Party's project, even though most 
Republicans didn't deny that they were equally benefiting from the knowledge produced by the OTA.

Right-wing parties may be right when they claim that TA institutions are sometimes leaning to left-wing preferences (in passing, we note that, to our best knowledge, opposite accusations are just missing), but it does not mean that they are not working for the Parliament as a whole and it has absolutely nothing to do with vested interests.

An exceedingly influential myth of neutrality may prove counterproductive for a TA institution, as its survival already tends to be questioned by political actors. Reflecting on OTA's closure, Bereano (1997: 173) considers that the Republicans simply wanted to remove agencies, governmental or parliamentary, which were too small to react and whose closure would not provoke a flood of adverse political reactions. What it means is that it seems difficult for a neutral organization, especially if it serves committees and not individual parliamentarians, to benefit from the massive support of parliamentarians when it is in danger, especially if this support puts them at political risk. In Belgium, the abolishment of the Flemish parliamentary institute of Technology Assessment (see van Oudheusden et al. 2015 for a detailed analysis), the Instituut Samenleving en Technologie (IST), bears striking similarities with the OTA story. After regional elections in 2009, a conservative majority led to a marked shift to the right. Budgetary restrictions were already put on the agenda of this majority, but the breaking out of the global economic crisis provided an additional justification for the imperative of cutting into public institutions to save money. In 2013, the TA institute became an easy prey and was abolished-actually, this only happened to IST even though the survival of four parliamentary institutes was jointly discussed. Thirteen years after its institutionalization, in spite of a widely-acclaimed work at the service of the Flemish Parliament, IST was still considered by some politicians as an institution marked by the political color of its main advocates (socialists and greens), who had become less influential in the meantime. However, despite the historical support of the socialist party (especially the former Minister Norbert de Batselier), it should be noted that the decision to give up IST in 2012 was approved by all political parties, except for the green party (Delvenne et al. 2012). This decision did not make it into the news: as Rabesandratana (2013) puts it, after an interview with the former Director of IST, it was a rather "quiet death".

To sum up our argument so far, acknowledging the politics of TA and debunking the myth of neutrality is a necessary task as well as a tough challenge ahead for TA institutions (see also Schneider and Lösch 2015). This section has shown, first, that the myth of neutrality is inconsistent with the practice and politics of Technology Assessment. Second, the 
illustrations of de-institutionalization processes in the US and in Flanders were outlined to additionally assert that, even while the myth would seem well embedded in political imaginations, it can rapidly be disembedded. Third, the myth proved ineffective, not to say counterproductive, to protect a TA institution at risk.

\section{Hitting the notes, but missing the music of politics?}

In the previous section we have argued that TA has politics, and that it is often a certain type of politics: conceptually and through its modes of operation (e.g. methods and concepts, publications, policy interventions), TA practitioners propose a more inclusive and equitable science-society relationship than is presently the case and act on their commitments to improve technology in society. In short, TA's politics is often about the democratization of, or broader participation in, scientific and technological options for policy-making. TA institutions indeed figure out innovative rationales and methods to democratize technological choices, facilitate interactions among experts, lay people and policy-makers, and embed deliberative and participatory modes of democracy.

This politics of democratization and participation partly gained traction in policy networks and governments because of elite anxiety about the side effects of our industrial modernity (i.e. air pollution, radioactivity, chemicals in food and water). As various scholars have shown (Hennen 1999, Delvenne et al. 2011, Delvenne 2011), TA emerged as an institutional response to, and embodiment of, the unfolding of 'reflexive modernization', in which modern societies and institutions are experiencing a largely unconscious process of self-undermining (Beck 1992, Beck et al. 1994, Giddens 1991, Beck et al. 2003). However, by taking unanticipated side effects as the engine of political change, these intellectual resources are mute about 'democratic politics' whatsoever, and thus are of little help to develop intellectual and pragmatic positions about the politics of TA. Following the famous expression coined by Brian Wynne, equipped with the conceptual resources of 'risk society' (Beck 1992) or 'reflexive modernization' (Beck et al. 1994), we end up with "hitting the notes, but missing the music" (Wynne 2006) of politics ${ }^{5}$. In what follows, we emphasize that more than simply

\footnotetext{
${ }^{5}$ For instance, by coining the terms 'subpolitics', Beck (1992) draws attention to the fact that we are looking for politics in the wrong place, as the 'real' political issues are now emerging in the 'techno-economic' sphere and being addressed by 'new social actors or movements', that is, beneath and beyond the democratic institutions of the nation-state (in passing, we note this also excludes parliamentary TA institutions). This diagnosis, which we oppose, serves as a basis for Beck's argument that politics thus needs to be reinvented and that classical political categories and ideologies are of little help to this aim.
} 
hitting the notes and missing — or being subjected to - the music of contemporary politics, TA should be a musician itself, that is, an agent of this music.

To Beck's credit, we admit that significant political changes can occur beyond and outside formal politics. But it cannot be used as smoke and mirrors: the political events sketched in the introduction are powerful reminders that political changes also originate inside formal politics, with equally tremendous effects. Belgian political philosopher Chantal Mouffe $(2000,2005,2016)$ forcefully argued that the most important political changes of 'reflexive modernity' had nevertheless been realized through the regular politics of democratic institutions. Democratic institutions can in fact be seen one of the most "stable repositories of knowledge and power that offer ready-made instruments at times of uncertainty" (Jasanoff 2004: 39).

Mouffe stresses that with a blind eye on power politics, reflexive modernization theorists ${ }^{6}$ and their followers risk undermining democratic politics. She contends that the related normative assumptions at the core of reflexive modernization theory depict a post-political world where conflict, dissensus and the very possibility of an adversarial democratic debate are pushed away or taken as the reminiscence of the ancient or backward world (Mouffe 2005) ${ }^{7}$. Against the background of deliberative democracy theories (those articulated by John Rawls and Jürgen Habermas), which are often seen at the core of TA's rationales and methodologies (Van Est and Brom 2010), Mouffe's political theory of democracy is based on agonistic pluralism, which acknowledges the unavoidability of antagonism and the unattainability of conflict resolution.

In that theory, Mouffe emphasizes the possibly positive aspects of certain forms of political conflict. It accepts a permanent place for such conflict in democratic politics, but seeks to show how people might cope with and channel this positively. Because a universal rational consensus is impossible, Mouffe pleas for the erection of agonistic democratic spaces where various hegemonic and counter-hegemonic practices can be confronted with each other and where politics is treated as constitutive of any social relation in a democratic order. The concepts of "hegemony" and "counter-hegemony" rest on the idea that every democratic order results from a series of practices of articulation through which the meaning of social institutions is temporarily and precariously fixed and an order is created in a context of

\footnotetext{
${ }^{6}$ These include Beck and his collaborators, but also Anthony Giddens, who authored a book entitled Beyond Left and Right (1994), in which he argues that the rise of individualization in a context of globalization is undermining traditional politics, making classical ideologies and political categories less and less relevant.

${ }^{7}$ Being "pushed away" doesn't mean that they vanish with the reflexive modernization era but, rather, that they have been "naturalized" or made "invisible", which, to us, appears as just another manifestation of incumbent power.
} 
contingency. "Things could always be otherwise and every order is predicated on the exclusion of other possibilities. Any order is always the expression of a particular configuration of power relations. What is at a given moment accepted as the 'natural' order, jointly with the common sense that accompanies it, is the result of sedimented hegemonic practices. Every order is therefore susceptible to being challenged by counter-hegemonic practices that attempt to disarticulate it in an effort to install another form of hegemony" (Mouffe 2013: 19-20) $)^{8}$.

Inspired by the previous works of Carl Schmitt (2006) and Jacques Derrida (see Fritsch 2008, Camargo 2013 and Carpentier and Cammaerts 2006), Mouffe considers that political identities consist of a certain type of we/they relation that is inherently constitutive of the political $^{9}$. In other words, collective political identities exist because they can define and organize themselves inside with regard to a "constitutive outside".

The challenge, for Mouffe, is to transform democratic institutions in order to provide a space where it becomes possible to turn antagonistic relations into agonistic relations. Whereas antagonism conceptualizes political association as a struggle among enemies who aim at destroying each other, agonism posits that opponents are not enemies but adversaries; by this, they acknowledge the others as legitimate and necessary actors to whom they can confront their political projects and worldviews. Under this approach, conflict is not only legitimate, it is also a guarantee that democracy is alive and inhabited by pluralism. As Van Bouwel and Van Oudheusden (2017) stress, this move marks a clear difference with deliberative democracy theorists in terms of 'meta-consensus' in democratic models, e.g., on how deliberative reasoning and (social) rationality are to be understood and invoked. Whereas deliberative theorists' meta-consensus postulates that dissent can and should in principle be resolved through deliberation and rational discussion, Mouffe's meta-consensus is conflictual

\footnotetext{
${ }^{8}$ Originally suggested by Gramsci, the notion of hegemony concerns the formation of consent rather than an exclusive domination on the other (Carpentier and Cammaerts 2006: 965). The hegemonic practices are the result of the political articulation of certain discourses and identities into a common project. This common project becomes "a social horizon" and represents a particular social order (Ibid). Meanwhile, counter hegemonic practices aim at making visible what the hegemonic ones tend to obscure and obliterate (Mouffe, 2008: 12).

${ }^{9}$ Mouffe embeds her conception of the political in the theories of Carl Schmitt (1996 [1932]). In particular, she points at the relation friend/enemy that she calls 'antagonism' to stress "the inherently conflictual nature of the political, which is the necessary starting point of any reflection on the purposes of democratic politics" (Mouffe 2016: 25, our translation). Schmitt's conception of the political has inspired many right-wing movements, and for that reason it has been very criticized in left-wing circles. As an engaged left-wing intellectual, Mouffe takes a more nuanced position: she endorses Schmitt's idea that political identities are constituted by and through certain types of we/they relations, but she clearly takes her distance with Schmitt's argument that pluralism and democracy cannot be reconciled. The theoretical and pragmatic challenge, for Mouffe, is to demonstrate that antagonism can be transformed in such a way that it gives rise to a form of we/they relation compatible with a pluralistic democracy.
} 
consensus, that is, an agreement on the impossibility to conclusively come to terms with dissent. In addition, for her, it should not be attempted to definitively resolve dissent on this meta-level, as doing so runs against the very meaning of democratic pluralism" (Van Bouwel and Van Oudheusden 2017: 8).

Because agonism takes power relations inherently constitutive of the political seriously, we argue that it could constitute a valuable source of inspiration for inventing a politics of TA. As TA has politics, in one way or another it engages in the constitution and contestation of power, which means that TA (in the broad sense, not only its own institutional embodiment but also the outcomes it produces) is also an integral part of power struggles in democratic spaces $^{10}$. Through its activities aiming at 'enlightening' policy-makers with robust knowledge about sociotechnical options, a TA institution exerts its power of influence from a critical position within democratic spaces (i.e. Parliaments). By doing so, it contributes to structuring possible fields of action in the governance of science and technology.

As we stressed in the previous section, TA practitioners sustain a particular form of 'knowledge', more encompassing than scientific knowledge alone, to achieve a greater impact on policy-making (Decker and Ladikas 2004). That form of knowledge, which is animated by particular values and visions of the future, materializes in concrete projects and contributes to shaping particular political identities that influence, in return, TA communities' own political identities. This is why, in the next section, we are led to argue not only for the acknowledgment that it is necessary to break down the myth of neutrality because TA has politics, but also for the understanding of TA as politics.

\section{Discussion: Inventing a politics of Technology Assessment}

The future of TA will in part depend on its capacity to invent its politics, which goes through rendering more explicit the political normativities and values that underlie its actions and projects. Such values or political standpoints are not just lying behind any TA project; they are in the minds and in the stances of both TA practitioners and participants to TA projects (Blok 2007), and they are profoundly ideological (Jasanoff and Simmet 2017). In other words, the point is not just that values and political standpoints are hidden from view; rather, they are jointly produced with TA projects, whose topicality, general aims, methods,

\footnotetext{
${ }^{10}$ This can be inferred from modern definitions of power in terms of relation, to paraphrase Foucault: 'The exercise of power consists in guiding the possibility of conduct and putting in order the possible outcome'; 'To govern, in this sense, is to structure the possible field of action of others' (Foucault 1982: 790).
} 
particular outcomes, etc., intersect with the political preferences, identities and hegemonic or counter-hegemonic practices of their imagined or actual addressees.

A TA institution and its addressees, institutional or otherwise, belong to a democratic order. In such an order, which is expected to be organized differently from one country to another, Mouffe stresses that it is to politics that one needs to turn to be able to activate meaningful social relations likely to drive democratic change. Political change in a democratic order will then result from the agonistic confrontation of political practices in search of hegemony. Through this confrontation of hegemonic and counter-hegemonic practices, political identities will be probed and refined. To be able to sustain specific practices resonating with their own politics, TA communities first have to be aware of what constitutes their own political identities. How should TA communities build, organize and define their political identities?

Mouffe's notion of 'constitutive outside'11 can be used as a guiding methodological principle to address this practical question. First, defining a 'constitutive outside' is especially helpful to prompt and make explicit a political identity. Second, a 'constitutive outside' allows sorting out TA supporters and adversaries, but it also provides relevant indications about which actors and what practices to actively support or oppose. Defining a 'constitutive outside' will then render possible for TA institutions and communities to recognize - and to be recognized by - the specific actors who appear as adversaries of TA, and those who are supporters of TA, sympathetic of the specific socio-technical order that TA strives for. Such endeavor requires reconstructing a boundary between 'us' and 'them', but in a dynamic, pragmatic and context-dependent way. Hence, such a contextually defined boundary between 'us' and 'them' will result from an inclusion/exclusion process that is revisable, evolving and heterogeneous (Delvenne et al. 2011: 39).

There is no point in defining in general terms what the 'constitutive outside' of a TA institution should be, nor to claim for universal insides or outsides which would be valid once-for-all for any TA institution. Rather, this section must be read as an attempt at stressing series of transversal questions and concepts that will guide TA practitioners and communities in the crucial task of inventing a politics by defining their own 'constitutive outside'. Such a process of political identity formation should primarily be conducted by the TA practitioners

\footnotetext{
${ }^{11}$ This notion highlights the fact that the constitution of an identity implies the establishment of a difference. We must accept that each identity is relational and that the condition of existence of an identity is the affirmation of a difference, that is, the determination of an 'other' that functions as its own 'outside'. Concerning collective identities, it is always a question of delimiting a 'us' compared to a 'them' (Mouffe 2016: 27-28, our translation).
} 
themselves, first at the national or regional level (where TA institutions are implemented), which would then allow for cross-national comparisons. Practitioners are indeed best positioned to embed their politics in modes of knowing and public reasoning attuned to their culturally and historically situated civic epistemologies (Jasanoff 2007). Second, a variety of reflections on what defines TA communities' constitutive outsides (in the plural) could adequately take place in European or international dedicated fora, such as the EPTA network, to highlight contrasts, differences and similarities among various politics of TA. Obviously, the definition of one TA's constitutive outside can never be set in stone: since democratic orders are always likely to be shifting as they are destabilized by (counter-)hegemonic practices, TA institutions' constitutive outsides have to be redefined according to the evolving political situations. In other words, because TA is equally about science and technology as it is about democracy (and related choices or options), the task of reflecting upon its own politics by (re)defining a constitutive outside could be routinized as good TA practices.

Imagining and defining a TA institution's 'constitutive outside' may prove difficult at the first sight. If some practitioners may easily identify the core values or the political normativities of their practices and projects, others may find this boundary work (Gieryn 1983) very uneasy to realize. As agonistic pluralism is about the democratic confrontation of hegemonic and counter-hegemonic practices, one way to sort this issue is to reverse the questioning: what values or political normativities can be identified as foreign to TA's rationales and epistemologies? Consequently, thinking symmetrically both in terms of exclusion (who are the adversaries of TA that are to be considered 'outside'?) and in terms inclusion (who are the allies of TA that fit 'inside'?) may facilitate the identity building process. Finally, once again, this process cannot be solidified once for all; rather, it must be a continuous process, fed by the imagined representations of the adversaries and the allies as their political positions and projects evolve over time.

With no claim to be exhaustive, we suggest three sites of politics strongly interrelated that can be used by TA practitioners as a heuristic to define a 'constitutive outside': the values, the visions of the future, and the hegemonic and counter-hegemonic practices. Those three sites should be considered as concentric circles, with values at the center. Indeed, the values are the starting point, as they influence the visions of the future that TA communities have; in turn, both values and visions then influence the embrace of or resistance to hegemonic or counterhegemonic practices (see the figure I below). 


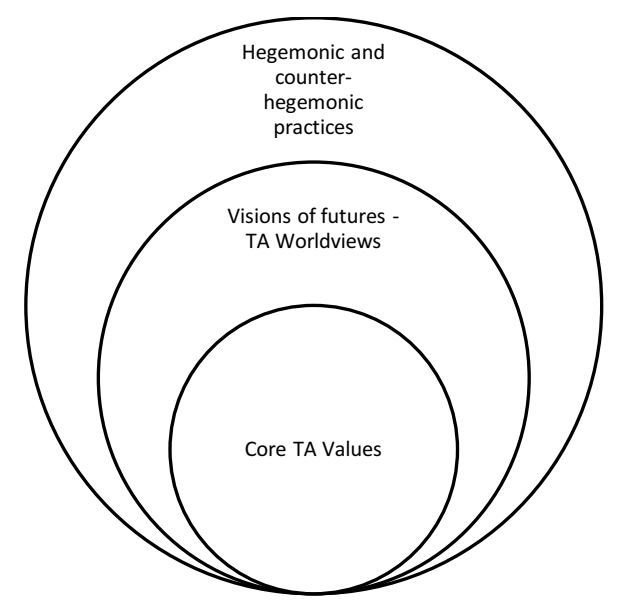

Figure I-TA and three sites of politics

These three sites of politics have always been there. Nevertheless, dazzled by the mirage of the myth of neutrality, TA communities have always failed to publicly admit the core values and the visions of futures that have always fed their political choices regarding which methods to prefer, which kinds of outcomes to publish or sustain and which kinds of futures to enable. As we have previously underlined, most scholarly attention has yet focused on procedural issues, for instance the methods that should be developed and the type of publics to include, leaving aside more substantial issues like the politics of TA. Below, we briefly explain each of these three sites of politics, suggesting concrete questions that may guide practitioners through their task of defining their own 'constitutive outside' when inventing their politics. For each site, we propose two sets of questions: the first concerns political identity, the second is about allies and adversaries.

\subsection{Defining a 'constitutive outside' through the values TA sustains}

Questions that may be asked:

- For political identity: What are the values our TA institution sustains? (Or what are the opposite values to what our TA institution sustains?) What are the core values and the values related to those core values? What are the values our TA institution absolutely refuses to break?

- For allies and adversaries: Who are the actors (i.e. political parties, public and private institutions, specific policy-makers) who share our values (or who are those who do not?)? 
As previously mentioned, the values a TA institution sustains should be the core and the starting point of every activity, every methodological choice, and every new point on the agenda of a TA institution. Therefore, to build its 'constitutive outside', answering questions related to values' identification should be of primary interest for a TA institution. For example, what values have become entrenched in the way we perceive our mission statements or perform our assessments (e.g. democratic or environmental citizenship)? What values appear as the most robust ones (e.g. participatory modes of decision-making, serviceability to decision-makers), and what other values are threatened or likely to be shifting (e.g. public trust in evidence)? Clear and regular statements on values constitute the prerequisite to meaningful political action, relating to the crucial question of why TA is doing what it is doing. Values are transversal meaning-making agencements, constitutive and performative of TA's motivations and goals. They feed and guide TA discourses and imaginaries, channel political ideologies, and they also provide justifications for action.

\subsection{Constitutive outside through far-reaching visions of future TA sustains}

Questions that may be asked:

- For political identity: In what society does our TA institution want to live? What are our visions of desirable futures with regard to that society we want to live in? (And what are the visions of undesirable futures?)? What can our TA institution do to help achieve these visions?

- For allies and adversaries: What policies, institutions, or policy-makers contribute to/share our visions of the future? (And what other actors, policies or institutions oppose our visions and propose alternative visions?)

If the values justify why a TA may choose to act in a particular way, normative decisions about visions always support particular ends. Therefore, questioning the "visionary" nature of TA's actions and the futures that TA desires to sustain is the next step for a TA institution to build its 'constitutive outside'. Visions are considered here as "imaginations of the future which exert a normative force in the present" (Ferrari et al. 2012: 217). They should describe the future states of the world that a TA collective esteems worth-attaining (Grin and Grunwald 2000, Grunwald 2004). In the same vein of vision assessment studies (Coenen 2014, Ferrari et al. 2012, Ferrari and Lösch 2017), "visioneering TA" (Schneider and Lösch 2015) should then explore and assess its own assumptions and its own imaginaries that feed 
its plausible desirable futures and shape its political identity. For example, what contributes to build a society that is considered as highly desirable (e.g. zero-carbon, socially just, knowledge- or labor-intensive)? What visions of future societies or imagined scenarios seem highly undesirable (e.g. extremely polarized, technophobic, distrustful of evidence or policymaking)? Visions of the future constitute a reservoir of imagination, roadmaps that offer "a rationale for a society's long evolutionary course while also constraining that society to performing the imagined lines of the story" (Jasanoff and Kim 2015: 29). As Ferrari and Lösch (2017:88) have already highlighted in particular case studies, visions are capable of mobilizing different forces in society by becoming a reference point of different interests. While entrenched in the past and oriented toward the future, visions are fully embedded in the present, as they influence research agendas, the allocation of resources (Ferrari et al. 2012: 216) and coordinate different actions (Ferrari and Lösch 2017: 77). Indeed, the present situation contains the seeds of the future and some futures appear more or less likely or desirable than others, according to the pattern of the present situation (Rip and Te Kulve 2008: 51). Choices, contingencies, and irreversibility are path-dependent, but they can nonetheless be opened or closed, as part of the potential directions that may be shaped politically by the TA institution and its allies.

\subsection{Constitutive outside through the hegemonic and counter-hegemonic practices TA} sustains

Questions that may be asked:

- For political identity: To what kind of (counter-)hegemonic practices does our TA institution want to contribute with specific projects? What kind of project (or imposed framing) should be turned down or resisted on the ground that it would sustain (counter-)hegemonic practices colliding with the values or visions of futures we strive for?

- For allies and adversaries: Do our TA projects - either those tasked with by our addressees (i.e. Members of Parliament or Government) or those our institution proactively initiates - support or collide with our values and visions of the future? What concrete projects could we put on our TA's agenda, and how positively (or negatively) do we expect them to be considered by our addressees? 
Closely related to the values and visions of the future that a TA sustains, the kind of projects the institution aspires to develop, steer, coordinate or promote because it aligns with (counter-)hegemonic practices worth supporting is another important step for drawing a line between 'us' and 'them' when defining a 'constitutive outside'. These sets of questions may also typically emerge from a situation in which a TA institution would a priori be competent to carry out a project (it would fall into its area of expertise), but may decide otherwise because the project strongly conflicts with its core values or entrenched visions of the future.

As Mouffe and Errejon stress, "democracy demands to have projects to identify with, with the conviction that there are alternatives for which it is worth fighting" (Mouffe and Errejon 2017: 51).

Concrete TA projects contribute to shaping broader political projects, as they always include questions of framing an issue, choosing a (set of) method(s), defining an appropriate communication strategy and generating outcomes such as reports, books, policy notes, participatory events, etc. TA projects can either result from a concrete demand, for instance from a Member of Parliament, or from a proactive strategy on the part of the TA institution. In the former case, even when the demand would come from a policy-maker considered as an adversary, the translation processes through which the practitioners will transform it into a question amenable to a TA treatment need to bear the imprint of the values and visions of the future the institution defends. In the latter case, the TA institution may decide to propose a particular project, or to step in a broader consortium of actors sharing values and worldviews, because it is a sensitive action to further embed its political agenda or to counter other practices in search of hegemony. The temporary democratic order resulting from hegemonic or counter-hegemonic practices is a particular manifestation of power as it will sediment certain options into a common project, while excluding other possibilities (Tambakaki 2009: 110). Deciding (not) to start or to take part in a project is always a normative question strongly related to the values and the worldviews TA sustains, independent from its capacity, expertise or legitimacy to carry it out.

\section{Conclusion}

"The hottest places in hell are reserved for those who maintain their neutrality in times of moral crisis"12.

\footnotetext{
${ }^{12}$ Adapted by John F. Kennedy, after Dante Alighieri, La Comedia Divina, trans. Geoffrey L. Bickersteth, “Inferno," canto 3, lines 35-42.
} 
In many places in the heartland of TA, political landscapes are upset by the accession to power of new political leaders, whose many are probably far from the political preferences and visions of the world sustained by TA communities. In our opinion, these events reveal a broader moral crisis, which requires a deeper reflection about the politics of TA. We have argued that issues stemming from contemporary politics may mutate into existential issues for TA institutions, and the myth of neutrality will not be of more help today than it was in the past. A director from a parliamentary TA institution (PTA) recently observed: "as happened before in other countries, our last elections have brought about a complete change of the political landscape with, among others, one very PTA supportive party being kicked out of the Parliament as well as many other supporters of PTA".

However, reflecting on the necessity to break with the myth of neutrality cannot be limited to finding a successful survival strategy, in a reactive and instrumental custom. 'Being neutral' has not only proved to be inefficient, we have also shown that it was flawed. The deeper commitment from TA communities that we argue for is to stop being agnostic to political stances, as TA not only has politics, it also is politics.

Given the fact that in TA communities, most of that politics was denied or kept out of view, these contemporary issues could be viewed as an opportunity: the one of inventing a politics of Technology Assessment. With a full awareness of its democratic politics, TA communities should be able to gain the trust and active support of political actors committed to the same ideals of democracy and knowledge-based policy-making. Furthermore, when these actors are more vulnerable, TA communities may become a bastion of democratic politics, actively working on the political terrain at empowering allies and equally disempowering adversaries.

The time has probably come for TA practitioners to be repeatedly criticized by, or invited to serve, a new class of addressees. We ask: are TA practitioners ready to serve extreme-right, authoritarian or populist political leaders in the exact same way they have been devoting their expertise to serve policy-making in the past? When they would be ready to do so, even only as a precarious survival strategy, are they able to be of service to such policy purposes given the obvious divergence with the substantial politics of TA that this article has stressed? Lastly, and maybe more importantly in this time of political uncertainty and epistemic ambiguity, are TA practitioners willing to acritically go down the path of any contemporary politics?

When confronted with politicians cherry-picking whatever truth-claim is available to reinforce their own or their addressees' preconceptions, TA communities should be able to 
enforce "serviceable truths, [which are] robust statements about the condition of the world, with enough buy-in from both science and society to serve as a basis for collective decisions" (Jasanoff 2017: 3). The stakes are high as it concerns fundamental constitution choices of how people wish to live with one another (Jasanoff and Simmet 2007: 754). Chantal Mouffe's notion of 'constitutive outside' provides an insightful starting point to render explicit the collective political identities of TA communities, as well as to draw contextual boundaries between TA supporters and adversaries. Defining this 'constitutive outside' at different sites of politics will also highlight what TA communities consider as "worthy" and "unworthy" (Jasanoff and Simmet 2007: 756) in democratic politics.

From here, we can ask if by making its values, visions and hegemonic practices more explicit, will a TA institution always be in a position of finding political support of TA supporters?

Values or visions are in principle what ties political collectives together. Therefore, it should be part of what probes and prompts political support. However, a distinction has to be made between implicit or explicit values and visions (Schneider and Lösch 2015), and it should not be taken for granted that shared values or visions will automatically result in increased political support. Indeed, for political reasons some addressees may prefer to be less vocal about particular values or visions, or they might limit themselves in endorsing them implicitly. In addition, at the cognitive level, not all political addressees show the same level of reflexivity concerning their own values and visions. Some of them may be less conscious of, or interested in, the values or visions inherent to their projects. The latter nevertheless underpin their concrete practices (e.g., actors in ministries setting up projects to shape innovation or technological trajectories), and they may align with TA communities' rationales and agendas. TA practitioners may thus behave in particular ways with these actors who could be convinced by TA's hegemonic practices, in order to gain their active support. However, as we consistently argue in this paper, the mobilization of TA allies cannot be limited to finding a protected niche from where to temporarily operate in an 'apolitical' fashion. The broader (re)construction site being (imperiled) democratic politics, TA communities convinced of the necessity to invent a politics of TA could well start their politicizing efforts in regular democratic institutions, before extending them to also include some 'subpolitical' arenas.

Breaking the myth of neutrality and becoming 'political TA' may sound too big a leap for TA communities. However, we consider that inventing a politics of TA is of the utmost importance to face the correlated changes in political and epistemic power games, triggered 
by the growing success of extreme-right, authoritarian or populist political leaders. Against the latter, political TA may even bridge right-wing and left-wing political positions, for example by rejecting crude political discourse filled with stark and simplistic binaries and augmenting political polarization (for example people-elite, good-bad, true-false or friendenemy), by refusing unsustainable promises of big upheaval in representative democracy-aswe-know-it, or by avoiding to propagate false hopes about the time needed to drive political change.

In such a challenging time for democratic politics, neutrality can definitively not be the TA answer.

\section{Acknowledgements}

This article was supported by Fonds De La Recherche Scientifique - FNRS. The authors want to express their gratitude to the two anonymous reviewers for their insightful and constructive comments on a first version of this article. The authors want to thank their colleagues Hadrien Macq and Tom op Het Veld very much for their careful readings and constructive comments on preliminary versions of this article. Lastly, many ideas defended in the article greatly benefited from the second author's affiliation with the STS Program at Harvard University (Kennedy School of Government).

\section{References}

Barland, M. \& Lovett, H. (2015), "The Future of Ageing. Policy report on technology, innovation and organisation in European health care", PACITA project, http://wp6.pacitaproject.eu/wp-content/uploads/2014/12/WP-6-report-web.pdf, last accessed on the 17th of November 2017.

Beck, U. (1992). Risk society: Towards a new modernity (Vol. 17). Sage.

Beck, U., Giddens, A., \& Lash, S. (1994). Reflexive modernization: Politics, tradition and aesthetics in the modern social order. Stanford University Press.

Beck, U., Bonss, W., \& Lau, C. (2003). The theory of reflexive modernization: Problematic, hypotheses and research programme. Theory, culture \& society, 20(2), 1-33.

Bereano, P. L. (1997). Reflections of a participant-observer: The technocratic/democratic contradiction in the practice of technology assessment. Technological Forecasting and Social Change, 54(2), 163-175.

Blair, P. (2013). Congress's Own Think Tank: Learning from the Legacy of the Office of Technology Assessment (1972-1995). Springer.

Blok, A. (2007). Experts on Public Trial: On Democratizing Expertise through a Danish Consensus Conference. Public Understanding of Science, 16, 163-182. 
Bütschi, D. \& Almeida, M. (2016). Technology Assessment for Parliaments-Towards Reflexive Governance of Innovation. In Klüver, L., Nielsen, R. Ø. \& Jørgensen, M.-L. (Eds.) Policy-Oriented Technology Assessment Across Europe: Expanding Capacities (pp. 64-76) London: Palgrave Macmillan.

Camargo, R. (2013). "Rethinking the Political: A Genealogy of the 'Antagonism' in Carl Schmitt through the Lens of Laclau-Mouffe-Žižek." CR: The New Centennial Review 13 (1):161-88.

Carpentier, N. and Cammaerts, B. (2006). Hegemony, democracy, agonism and journalism: an interview with Chantal Mouffe. Journalism studies, 7 (6). pp. 964-975.

Coenen, C. (2014). "Transhumanism and Its Genesis: The Shaping of Human Enhancement Discourse by Visions of the Future." Humana Mente 26:35-58.

Decker, M., \& Ladikas, M. (2004). Technology Assessment in Europe; between Method and Impact-The TAMI Project. In: Bridges between Science, Society and Policy (pp. 1-10). Springer Berlin Heidelberg.

Delvenne, P. (2011). Science, technologie et innovation sur le chemin de la réflexivité. Enjeux et dynamiques du Technology Assessment parlementaire. Louvain-La-Neuve: Academia L'Harmattan.

Delvenne, P., Fallon, C. \& Brunet, S. (2011). Parliamentary Technology Assessment Institutions as Indications of Reflexive Modernization. Technology in Society, 33(1-2), 3643.

Delvenne, P., Evers, J. \& Rosskamp, B. (2012). Parliamentary TA in Flanders (Belgium) In: Ganzevles, J. \& van Est, R. (Eds) TA Practices in Europe. Deliverable 2.2. PACITA Project, European Commission. Brussels: European Commission.

Delvenne, P., Charlier, N., Rosskamp, B. \& Van Oudheusden, M. (2015) De-and ReInstitutionalizing Technology Assessment in Contemporary Knowledge-Based Economies. Technikfolgenabschätzung-Theorie und Praxis, 24(1), 20-28.

Delvenne, P. (2017). Responsible research and innovation as a travesty of technology assessment? Journal of Responsible Innovation, 1-11.

Ferrari, A., Coenen, C. and Grunwald, A. (2012). "Visions and Ethics in Current Discourse on Human Enhancement." NanoEthics 6 (3):215-29.

Ferrari, Arianna, and Andreas Lösch. 2017. "How Smart Grid Meets In Vitro Meat: On Visions as Socio-Epistemic Practices.” NanoEthics 11 (1):75-91.

Foucault, M. (1982). The subject and power. Critical inquiry, 8(4), 777-795.

Frankfurt, H. G. (2009). On bullshit. Princeton University Press.

Fritsch, M.. (2008). “Antagonism and Democratic Citizenship (Schmitt, Mouffe, Derrida).” Research in Phenomenology 38 (2):174-97. 
Fuller S. (2016). "Science has always been a bit "post-truth", The Guardian, https://www.theguardian.com/science/political-science/2016/dec/15/science-has-always-beena-bit-post-truth, last accessed on 17th November 2017.

Gibbons, J. \& Johns, L. (2006). "Oral History. Assistant to the President for Science and Technology and Director of the White House Office of Science and Technology Policy", Presidential Oral Histories, University of Virginia, https://millercenter.org/thepresidency/presidential-oral-histories/john-gibbons-and-lionel-johns-oral-history-2006, last accessed on the 17th of November 2017.

Giddens, A. (1991). Modernity and self-identity: Self and society in the late modern age. Stanford university press.

Giddens, A. (1994). Beyond left and right: The future of radical politics. Stanford University Press.

Gieryn, T.F. (1983). Boundary-Work and the Demarcation of Science from Non-Science: Strains and Interests in Professional Ideologies of Scientists. American Sociological Review, 48(6), 781-795.

Grin, J. \& Grunwald, A. (2000). Vision Assessment: Shaping Technology in 21st Century Society. Towards a Repertoire for Technology Assessment. Berlin: Springer.

Grunwald, A. (2004). Vision Assessment as a new element of the FTA toolbox. New horizons and challenges for future-oriented technology analysis. Proceedings of the EU-US Scientific Seminar: New Technology Foresight, Forecasting \& Assessment, Sevilla, pp. 13-14.

Hennen, L. (1999). Participatory technology assessment: a response to technical modernity? Science and Public Policy, 26(5), 303-312.

Hennen, L. \& Nierling, L. (2015). Taking Stock of TA in Europe and Abroad. Introduction to the Thematic Focus. Technikfolgenabschätzung - Theorie und Praxis, 24(1) 4-10.

Hennen, L. \& Nierling, L. (2017) "The Politics of Technology Assessment." Call for Papers, 3rd European Technology Assessment Conference, Cork, May 17-19, 2017. http://cork2017.technology-assessment.info/images/files/Call-for-Papers---The-politics-ofTA.pdf.

Jasanoff, S. (Ed.). (2004). States of knowledge: the co-production of science and the social order. Routledge.

Jasanoff, S. (2007). Designs on nature: Science and democracy in Europe and the United States. Princeton University Press.

Jasanoff, S. (2017). "Perspective: Back from the Brink Truth and Trust in the Public Sphere." Issues in Science and Technology, 33 (4) 2017, 25-28.

Jasanoff, S., \& Simmet, H. R. (2017). No funeral bells: Public reason in a 'post-truth'age. Social Studies of Science, 47(5), 751-770. 
Kunkle, G. C. (1995). New challenge or the past revisited? : The office of technology assessment in historical context. Technology in Society, 17(2), 175-196.

La Porte, T. M. (1997). New opportunities for technology assessment in the post-OTA world. Technological Forecasting and Social Change, 54(2-3), 199-214.

La Porte, T. (2013). Technology assessment at the American Congress and the future of technology assessment. In: Presentation at a Symposium on Technology Assessment in the Walloon Parliament, March 8, 2013, Namur.

Lynch, M. (2017). STS, symmetry and post-truth. Social Studies of Science, 47(4), 593-599.

Mann, T. (1924). The Magic Mountain, HT Lowe-Porter, New York: Vintage.

Mironesco, C. (1997). Un enjeu démocratique: le technology assessment: maîtrise de la technologie aux Etats-Unis et en Europe. Georg: Institut européen de l'Université de Genève.

Mouffe, C. (2000). The democratic paradox. Verso.

Mouffe, C. (2005). On the political. Psychology Press.

Mouffe, C. (2008). "Art as an Agnostic Intervention in Public Space”, Art and Democracy, Open 2008/No. 14, 6-15.

Mouffe, C. (2013). Agonistics: Thinking the world politically. Verso.

Mouffe, C. (2016). L'illusion du consensus. Albin Michel.

Mouffe, C., and Errejón I. (2017). Construire Un Peuple: Pour Une Radicalisation de La Démocratie. Editions du Cerf.

Rabesandratana, T. (2013). A Quiet Death. Interview with Robby Berloznik on the closure of IST. In: Research Europe 24 (2013), p. 6

Rosskamp, B. (2017). Futures and Remakings of Policy-oriented Technology AssessmentCase Studies from Wallonia, Portugal and the Czech Republic (Doctoral dissertation, Université de Liège, Liège, Belgique).

Schneider, C., \& Lösch, A. (2015). What about your futures, technology assessment? An essay on how to take the visions of TA seriously, motivated by the PACITA conference. Technikfolgenabschätzung-Theorie und Praxis 24 (2): 70-74.

Sismondo, S. (2017). Post-truth? Social Studies of Science, 47(4), 3-6.

Schmitt, Carl. (1996). The Concept of the Political. Chicago: University of Chicago Press.

Tambakaki, P. (2009). Cosmopolitanism or Agonism? Alternative Visions of World Order. Critical Review of International Social and Political Philosophy 12 (1):101-16. 
Van Bouwel, J., \& Van Ousheusden, M. (2017). Participation beyond consensus? Technology assessments, consensus conferences and democratic modulation. Social Epistemology 31 (6): 497-513.

Van Eijndhoven, J. C. (1997). Technology assessment: Product or process?. Technological Forecasting and Social Change, 54(2-3), 269-286.

Van Est, R., \& Brom, F. (2012). Technology assessment: Analytic and democratic practice. Encyclopedia of applied ethics, 4, 306-320.

Van Kasteren, J. (2015). "It's not just science", VolTA magazine, Issue 8, https://www.rathenau.nl/en/file/527/download?token=iRZzCgFd, last accessed on November $17^{\text {th }}, 2017$.

Van Oudheusden, M. (2014). Where are the politics in responsible innovation? European governance, technology assessments, and beyond. Journal of Responsible Innovation, 1(1), $67-86$.

Van Oudheusden, M., Charlier, N., Rosskamp, B., \& Delvenne, P. (2015). Broadening, deepening, and governing innovation: Flemish technology assessment in historical and sociopolitical perspective. Research policy, 44(10), 1877-1886.

Wenger, E., Trayner, B. (2015). Communities of practice - A Brief introduction. Available at http://wenger-trayner.com/introduction-to-communities-of-practice/, last accessed on November $17^{\text {th }}, 2017$.

Whiteman, D. (1997). Congress and policy analysis: a context for assessing the use of OTA projects. Technological Forecasting and Social Change, 54(2-3), 177-189.

Winner, L. (1980). Do artifacts have politics?. Daedalus, 121-136.

Wood, F. B. (1997). Lessons in technology assessment: Methodology and management at OTA. Technological Forecasting and Social Change, 54(2-3), 145-162.

Wynne, B. (2006). Public engagement as a means of restoring public trust in science-hitting the notes, but missing the music?. Public Health Genomics, 9(3), 211-220. 